Journal of Engineering and Applied Sciences 14 (Special Issue 7): 10122-10130, 2019

ISSN: 1816-949X

(C) Medwell Journals, 2019

\title{
Isolation of Legionella Pneumophila from Air of Water Coolers in Baghdad
}

\author{
${ }^{1}$ Nassir Abdul Hussein AL-Hindawi, ${ }^{2}$ J. K. Abed and ${ }^{2}$ Jassim M. Salman \\ ${ }^{1}$ Department of Medical Laboratory Technology, Al-Nisour University College, Baghdad, Iraq \\ ${ }^{2}$ AL-Nisour University College, Baghdad, Iraq
}

\begin{abstract}
The bacterium Legionella is ubiquitous genus, belongs to the family Legionellaceae, comprising 52 species. The most common species is Pneaumophila, causing a febrile and pneumonic illness, found primarily in aquatic habitat and thrive at warm temperature. It is capable of surviving extreme ranges of environment, surviving up to 14 months in water. Legionella is water bacterium isolated from air conditioning systems, cooling waters and humidifiers in offices and hospitals. It gets to human mostly through blowing air from air of water cooling systems or aspiration of contaminated drinking water fumes. Infection may have fatality rate of up to $50 \%$. They have been isolated from waters and ducts of aircoolers in various location in Baghdad. Sample were placed in test tubes containing nutrient broth with $50 \%$ yeast extract and taken immediately to a diagnostic laboratory at Al-Nisour University College in Baghdad city. Subcultures from each tube were taken to inoculate each of nutrient agar plate with 5\% yeast extract, blood agar plates, EMB plates, S-S agar plates gram staining was made. All plates were placed in a desiccator with a beaker of water and incubated at $35^{\circ} \mathrm{C}$ except BA for 3 days. Colonies were described and sub cultured for purity, then gram stained and reported modified gram stain was applied for Legionella cells, Legionella was diagnosed in 27 samples out of 114 (23.7\%). Bacterial genera repeatedly isolated and diagnosed were: Streptococcus, Staphylococcus, Escherichia, Pseudomonas, Klebsiella, Legionella, Agrobacter and Bacillus. The frequent isolate was Escherichia coli. Shelf life of Legionella in water was determined to control it by heat a temperature of $80^{\circ} \mathrm{C}$ destroyed the cells in $1 \mathrm{~h}$. The heat tolerance of the cells was found to be $70^{\circ} \mathrm{C}$ but not $75^{\circ} \mathrm{C}$. Persistence of Legionella in river water last up to 3 months. Cells were counted by the method of dilution to extinction. Legionella cell isolated have high resistance to antimicrobial agents, except to Amikacin, Nalidixic acid and Nitrofurantoin.
\end{abstract}

$\underline{\text { Key words: Legionellaceae, Baghdad, antimicrobial agents, aspiration, environment, diagnostic laboratory }}$

\section{INTRODUCTION}

The bacterium Legionella was discovered in 1976 by microbiologists at the Center of Disease Control and Prevention (CDC) during an investigation on epidemic of Pneumonia-like infections reported at a convention of the American legion in Philadelphia in 1976. It produces a lobar segmented or patchy pulmonary infection, causing acute purulent Pneumonia involving the alveoli with a dense intra alveolar exudate at macrophages, polymorphonuclear leukocytes, red blood cells and proteinaceous material, (Velonakis et al., 2010; Atlas, 1999; Hensley, 2009; Barbaree et al., 1987; Shivaji et al., 2014; Dennis et al., 1984). The disease Legionnaires was reported to cause $15 \%$ morbidityand accompanied by renal failers and pericarditis (Chamberlain et al., 2017; Madigan and Martinko, 2005; Mahoney et al., 1992; Ensminger, 2016). Legionella produce a lobar segmented or patchy pulmonary infection, like other bacterial pathogens, causing acute purulent pneumonia, involving the alveoli with a dense intra alveolar exude of macrophages and polymerorphonuclear leukocytes, red blood cells and proteinaceous material (Phin et al., 2014; Sabria et al., 2006). In the USA about 30 infections appear per 100,000 residences, mostly in the Summer (Sabria et al., 2006; Albert-Weissenberger et al., 2007). The outbreak of legionnaires was repeatedly reported but no person to person infection was noted (Albert-Weissenberge et al., 2007; Phin et al., 2014). The bacterium is found in water (Al-Sulami et al., 2013; Hsu et al., 1984; Kukla-Lamount, 2006). And inrivers, lakes, ponds, soil, moist mud, cooling towers, humidifiers in offices, hospitals, swimming pools,thermal water, sewage and air conditioning systems, (Atlas, 1999; Hubber and Roy, 2010; Nick and Bennie, 2011; Barbaree et al., 1987; Hughes and Steele, 1994; Riffard et al., 2001). Legionella is a facultative intracellular pathogen of some protozoa like Hartmenella (Greub and Raoult, 2003; Alag and Al-Salmi, 2013). Legionella is capable of surviving extreme range of environment for 14 month in water. In the intra cellular, amoeba provide protection from chlorine. Both virulent and a virulent strain are phagocytosed. A virulentstrain can multiply inside the phagocytes but nonvirulent strains

Corresponding Author: Nassir Abdul Hussein AL-Hindawi, Department of Medical Laboratory Technology, Al-Nisour University College, Baghdad, Iraq 


\section{J. Eng. Applied Sci., 14 (Special Issue 7): 10122-10130, 2019}

do not (Anonymous, 2005). The incubation perivale is 2-10 days with mortality of 15 days. After contact fever begins 1-7 days accompanied by headache and myalgia. There are 52 species of Legionella identified, the most common species are; L. pneumophelia causing pneumonia illness and L. micdadi is also a frequnet cause of Legionella disease and the causative agent of pontiac fever. The species associated with Legionnaire are L. pneumophela and L. longbeachiae, L. bozemanae, L. Feeloii, L. dormothii, Jordanis, L. oahidgenesis.

To date 20 species of Legionella are documented as human pathogens. Insero typing there is cross reaction between species and other gram negative bacteriamay (Travis et al., 2012). The organism can be recovered from bacterial washings, pleural fluid, lung biopsy specimen and rarely from blood. Isolation from sputum is more difficult because of the predominance of normal of flora (Phin et al., 2014). In gram staining of Legionella the counter stain safranine is replaced with dilute carbol buchsin. Other staining methods are silver impregnation and the antibody coupled fluorescent dyes and immunoperoxidase.

Rapid examination of Legionella antigen in urine and other body fluid has been accomplished by Enzyme Immunossay (EIA) after the onset of symptoms (Madigan and Martinko, 2005; Sabria et al., 2006). Serologically L. pneumophila serogroups constitute $80-90 \%$ of all Legionella infections (Barbaree et al., 1987). Legionella's disease is known as a typical pneumonia that infect the lung after inhaling contaminated water. It was reported that contaminated water supply, according to the Detroit Free Press, killed 12 people and made 91 others sick as reported at the Annual American Society for Microbiology (ASM) meeting in New Orleans. Legionella toxin can damage the kidneys and cause respiratory failure. The cells are gram negative; aerobic, non-encapsulated, thin bacilli, motile by single polar flagellum, $0.3-0.9$ by $2-20 \mu \mathrm{m}$ (Hughes and Steele, 1994). Growth limits are $15-42^{\circ} \mathrm{C}$ with generation time of 99 min (Albert-Weissenberger et al., 2007). Infection by his bacterium results from inhalation of aerosol droplets of water that carry the cells. Legionella can multiply in temperatures of $20-40^{\circ} \mathrm{C}$ with an optimum growth temperature of $32-35^{\circ} \mathrm{C}$ and can survive at $0-680^{\circ} \mathrm{C}$ at $\mathrm{pH}$ 5.0-8.5 (Deadens, 2008; Bauer et al., 2008).

For control, ozone dissolve in water does not last long distance as reported by the Association of Water Technology in 2000. Filtration using filters of pore size $0.2 \mu \mathrm{m}$ was used. Copper-silver ionization between $0.2-0.4 \mu \mathrm{g} / \mathrm{L}$ copper was used and $0.04 \mathrm{mg} / \mathrm{L} . \mathrm{S}$, liter was applied.

Use of heat over $60^{\circ} \mathrm{C}$ inhibit. Legionella hyper chlorination is recommended (Madigan and Martinko, 2005). Monochloramine is used with typical dosage of
1-10 mg/L. Other methods used for control of Legionella were hyper silver ionization, chlorine dioxide and monochloroamine (Deadens, 2008).

\section{MATERIALS AND METHODS}

Sample were: waters, scrapings from plates and ducks of air coolers from several locations in Baghdad city during the months of July and August. 2018, totaling 114 samples (Barbaree et al., 1987). Samples were placed in test tubes of nutrient broth containing $5 \%$ yeast exact, aseptically and immediately taken to the microbiological laboratory at Al-Nisour University College in Baghdad. If longer time was needed for the therefor, the samples were kept refrigerated. All tubes were incubated for 3 days at $35^{\circ} \mathrm{C}$. We followed several references in diagnosing bacteria (Fisher, 2014; Labora, 2018). Bacteriological culture media plus our own technique of long experience in teaching Bacteriology. After incubation, all tubes showed growth as turbidity, some tubes have pellicles with or without a precipitate. From the pellicles, loopfuls were taken to inoculate the following media in duplicate: blood agar plates, nutrient agar plates, EMB agar plates and SS agar plates and for gram staining. Nutrient agar plates as well as nutrient broth contain $5 \%$ yeast extract whenever mentioned. Samples from the turbid portion and from the precipitate were aspirated with sterile needle and syringe for culturing and staining.

The blood agar plates were placed in a desiccator containing a beaker of water and the desiccator was placed in the incubator at $35^{\circ} \mathrm{C}$. All colonies growing on the blood agar after $24 \mathrm{~h}$ were marked at the back of plates. The appearing colonies on the blood agar were described and gram stained and sub-cultured on BA plates for purity. The same plates were incubated for $48 \mathrm{~h}$ longer. (That is $72 \mathrm{~h}$ of Incubation), using the desiccator, all colonies on all other solid media were sub-cultured on the same media for purity. All growing colonies were described and gram stained. Microscopies and physiological tests including IMViC tests for coliforms were made. All growing bacteria were identified and recorded in the results chapter. The counter stain suspected to be Legionella cells was diluted carbon fusion instead of safranin. The blood agar plates after $72 \mathrm{~h}$ incubation showing new colonies are suspected the Legionella. They were sub-cultured for purification and incubated the same day for 3 days. Colonies appearing were described, gram stained and the following tests were conducted:

Oxidase, urease, lecithinase, coagulase, hipurate test, gelatin liquefaction, catalase and nitrate reduction. When all of these tests were positive, plus the typical colonial description and gram staining cells were photoed as being Legionella. All other colonies appearing on solid media were identified and listed in the results chapter. For 


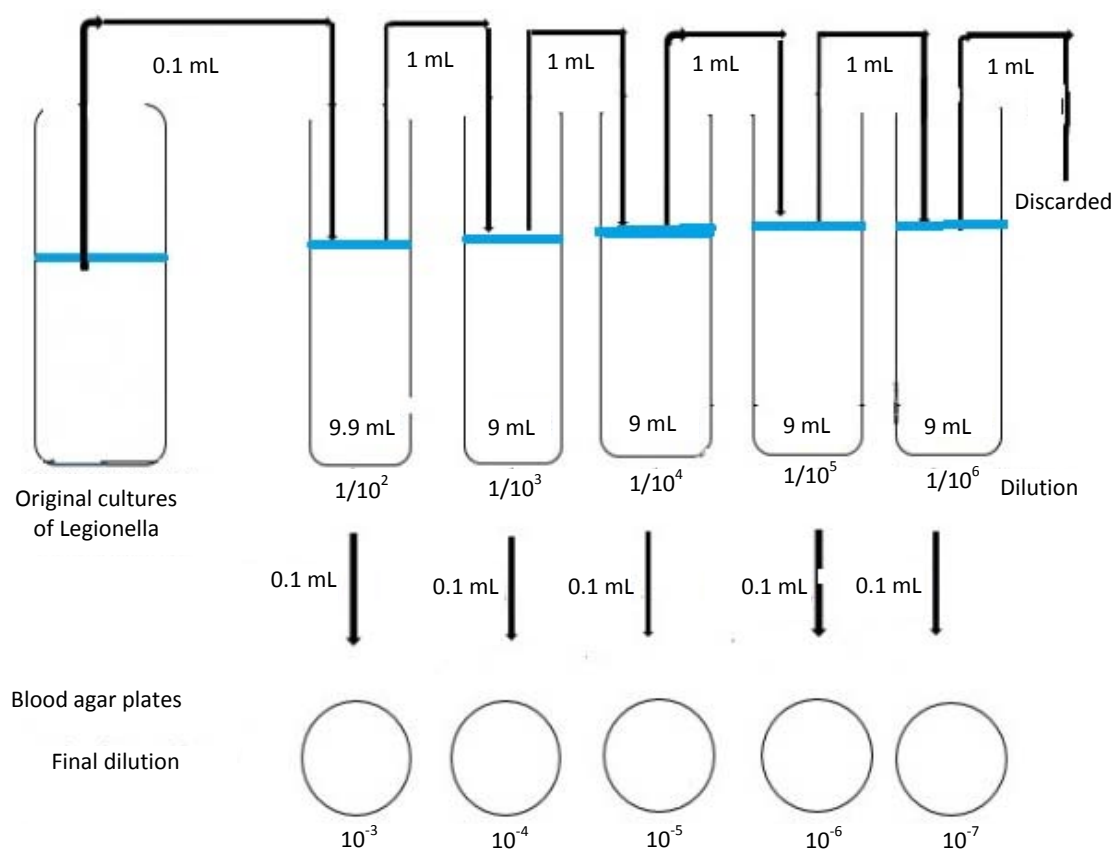

Fig. 1: Count of Legionella cells by dilution to extinction

control of Legionella in water, practical method is by heat. Cell count at $0 \mathrm{~h}$ will determined. The cell count used was by dilution to extinction. This method is illustrated in the following Fig. 1.

Shelf life of Legionella: Known count of Legionella cells was stored in Dijla River water at room temperature for up to 4 months and counted after $1 / 2$ month, 1-4 months, using the counting method of dilution to extinction. In each step, the blood agar plates were incubated at $35^{\circ} \mathrm{C}$ for 4 days in a desiccator, under a humid atmosphere.

Effect of heat on viability and cells tolerance of Legionella: Several colonies of Legionella from blood agar plates were emulsified in $20 \mathrm{~mL}$ of sterile Dijla River water and counted as mentioned. The $2 \mathrm{~mL}$ of the cell suspension were transferred to sterile test tubes marked $40,50,60,70,75$ and $80^{\circ} \mathrm{C}$. Tubes were exposed to heat as marked in an oven set for the temperatures indicated, kept in for $1 \mathrm{~h}$. The amount of $0.1 \mathrm{~mL}$ was transferred to the blood agar plates, streaked and incubated as was mentioned for 4 days. Cells were counted as done in the cell count diagram. For sensitivity of Legionella to antimicrobial agents several colonies of Legionella from blood agar plates were emulsified in sterile saline. Blood agar plates were streaked with cotton swabs. Discs of antimicrobial agents were placed and plates were incubated as was mentioned for 4 days. Inhibition zones, if any were recorded.

\section{RESULTS AND DISCUSSION}

The incorporation of yeast extract at 5\% in the nutrient broth and agar was to provide iron and cysteine for Legionella. After $72 \mathrm{~h}$ of incubation, all nutrient broths showed turbidity. Some with pellicles or precipitate or both. From the pellicles, gram stain showed the presence of gram negative and gram positive bacilli with gram positive cocci, (Fig. 2). The turbid portion of the broth showed numerous Gram negative rods with some gram positive bacilli and cocci (Fig. 3). the precipitate revealed gram negative bacilli with some gram positive bacilli and cocci (Fig. 4).

\section{Results of bacterial diagnosis}

Escherichia coli: Gram negative cells, showing metallic green sheen on EMB, lactose positive IMViC test++--, motile cells, streptococcus faecalis small on nutrient agar, glistening on nutrient agar and blood agar plates, non-hemolytic, gram positive cocci, forming short chains in the broth, doesnot grow on SS agar.

Proteus vulgaris: Gram negative motile rods, spreading colonies on nutrient agar and blood agar, mucoid colonies, non-hemolytic, forming short chains in broth does not grow on $\mathrm{SS}$ agar. $\mathrm{H}_{2} \mathrm{~S}$ positive, giving fetid odor.

Staphylococcus aureus: Gram positive cocci in clusters, dull white colonies, turns yellowish in time, colonies are 


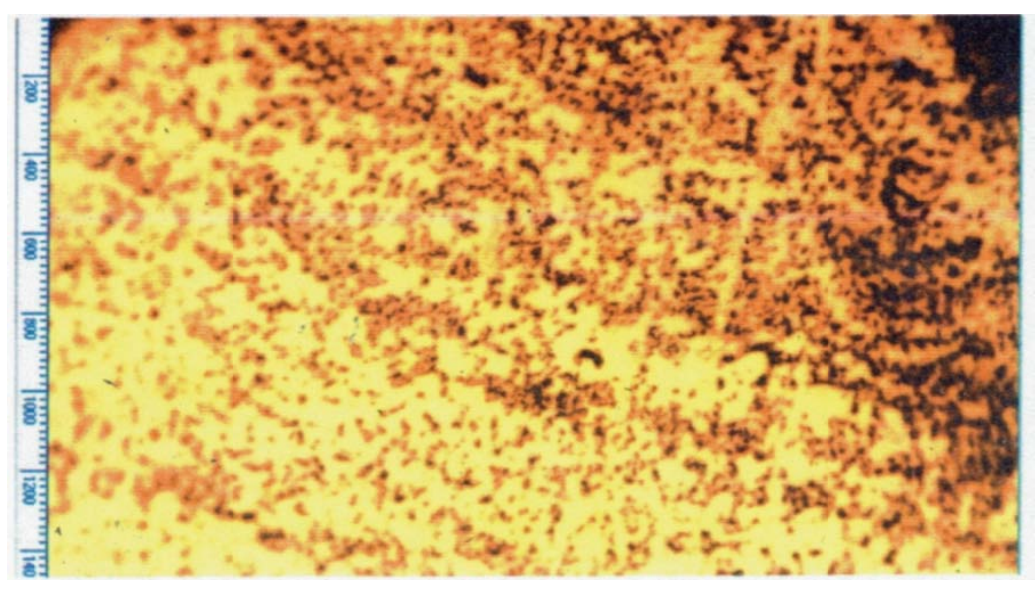

Fig. 2: Gram negative bacilli and gram positive bacilli and cocci seen in the pellicle of broth from water samples of water of air cooler (1000X)

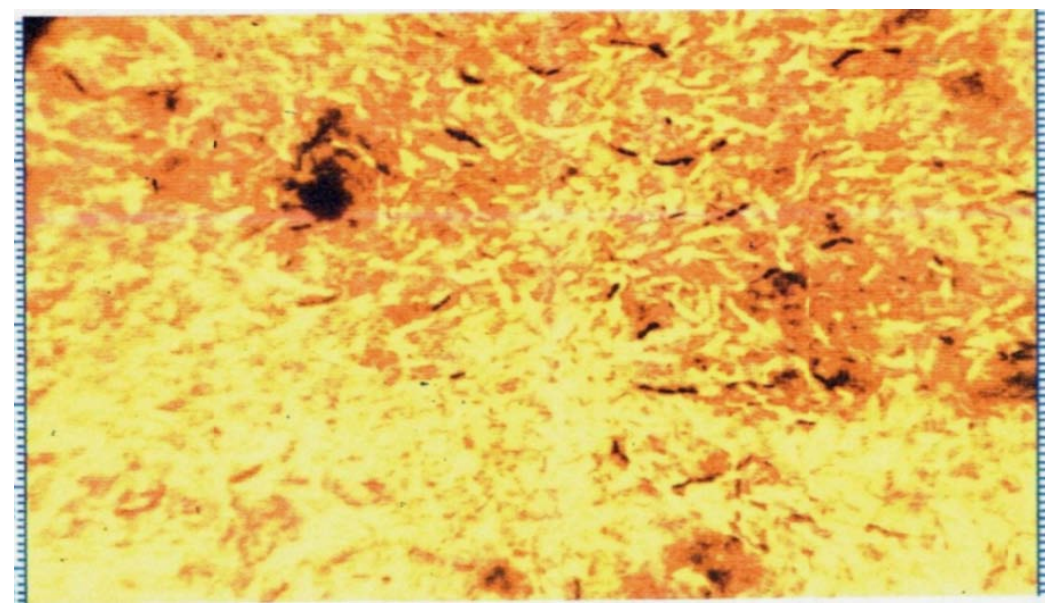

Fig. 3: Gram negative rods with gram positive bacilli and cocci seen from the turbid portion of nutrient broth, samples were from ducts of water air coolers (1000X)

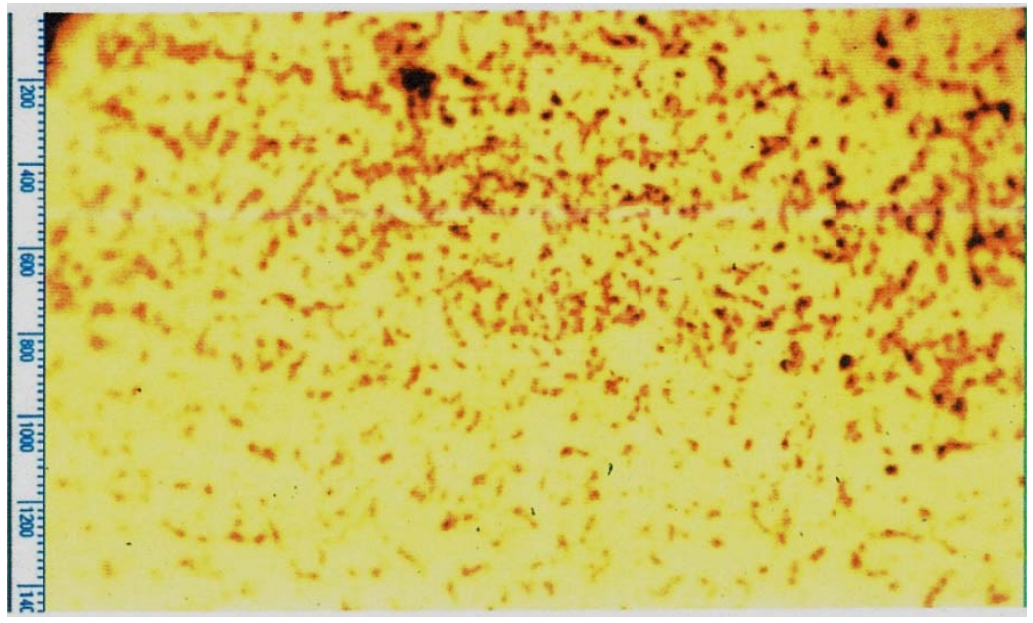

Fig. 4: Bacteria seen from the precipitate of nutrient broth showing gram negative bacilli with gram positive bacilli and cocci. Samples were scrapings from ducts of water air coolers (1000X) 
raised, entire, beta hemolytic on blood agar plates does not grow on EMB or SS agar, resist $80^{\circ} \mathrm{C}$ for $15 \mathrm{~min}$, tolerate $8 \% \mathrm{NaCl}$, catalase positive.

Pseudomonas: Gram negative motile rods, spreading with a slight fluorescent blue color, giving aromatic sweet odor, grow on EMB.

Bacillus subtilis: Gram positive rods, forming spores on nutrient agar show white dry colonies. Cells are motile, forming chains.

Bacillus stearothermophilis: Dry white rough colonies on nutrient agar, gram positive bacilli sporeforming when emulsified in saline and autoclaved at $121^{\circ} \mathrm{C}$ for $15 \mathrm{~min}$ and sub-cultured. it grows again because of their heat-resistant spores.

Streptococcus faecalis: Gram positive cocci, colonies are small rounded on nutrient and blood agar, cells from short chains in broth do not grow on ENB or SS agar.

(a)

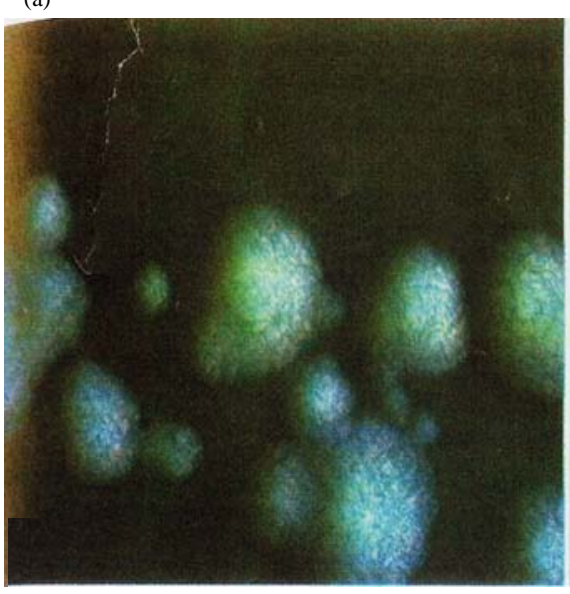

Klebsiclla pneumoniae: White mucoid colonies, gram negative non-motile rods with capsule. Ferment lactose and sucrose.

Legionella: Colonies on blood agar plates, after $72 \mathrm{~h}$ and longer at $35^{\circ} \mathrm{C}$. Appear thin, flat, circular with a slight blue colors, showing internal granules and giving a cut glass appearance as was shown by Bailey and Scotts in diagnostic Bacteriology, reference Bailey and Scotts (Fig. 5). The Legionella cells are Gram negative, thin, motile encapsulated (Fig. 6). In prolonged incubation, cells become elongated (Fig. 7). Physiological and biochemical tests as were mentioned in the materials and methods chapter were positive. Our results strongly indicated a highly polluted tap water supply in Baghdad city. Since, Two pathogenic bacteria, Legionella and Klebsiella were found. it is likely other bacterial pathogens, protozoa or helminths are expected, making our water supply not potable for the eight million inhabitants.

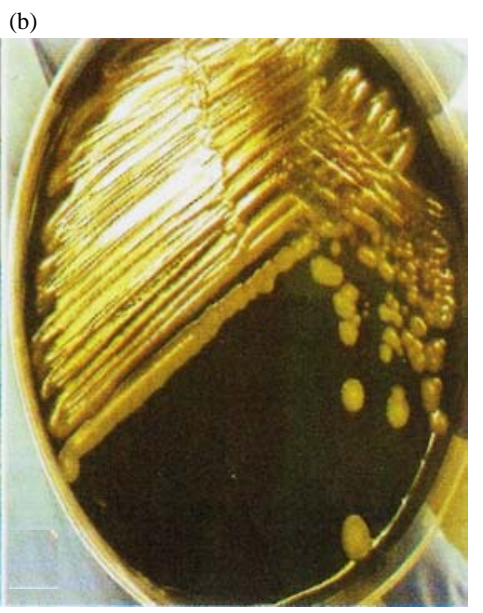

Fig. 5(a, b): Legionella colonies, curtesy of Baily and Scotts, diagnostic bacteriology, 11th Edition, 2017

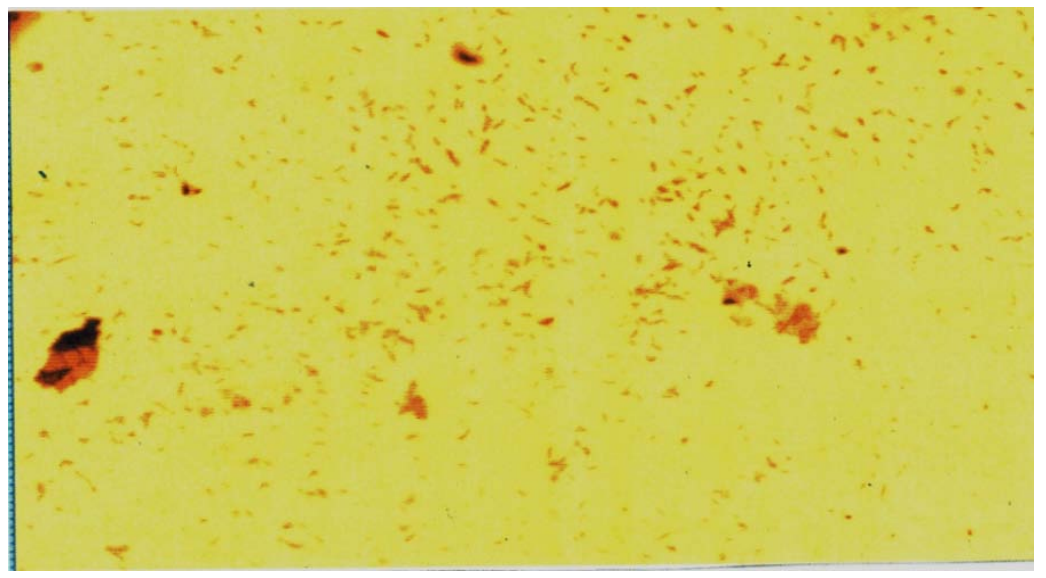

Fig. 6: Legionella cells grown on blood agar plates after $72 \mathrm{~h}$ of incubation at $35^{\circ} \mathrm{C}(1000 \mathrm{X})$ (Edition, 2017) 


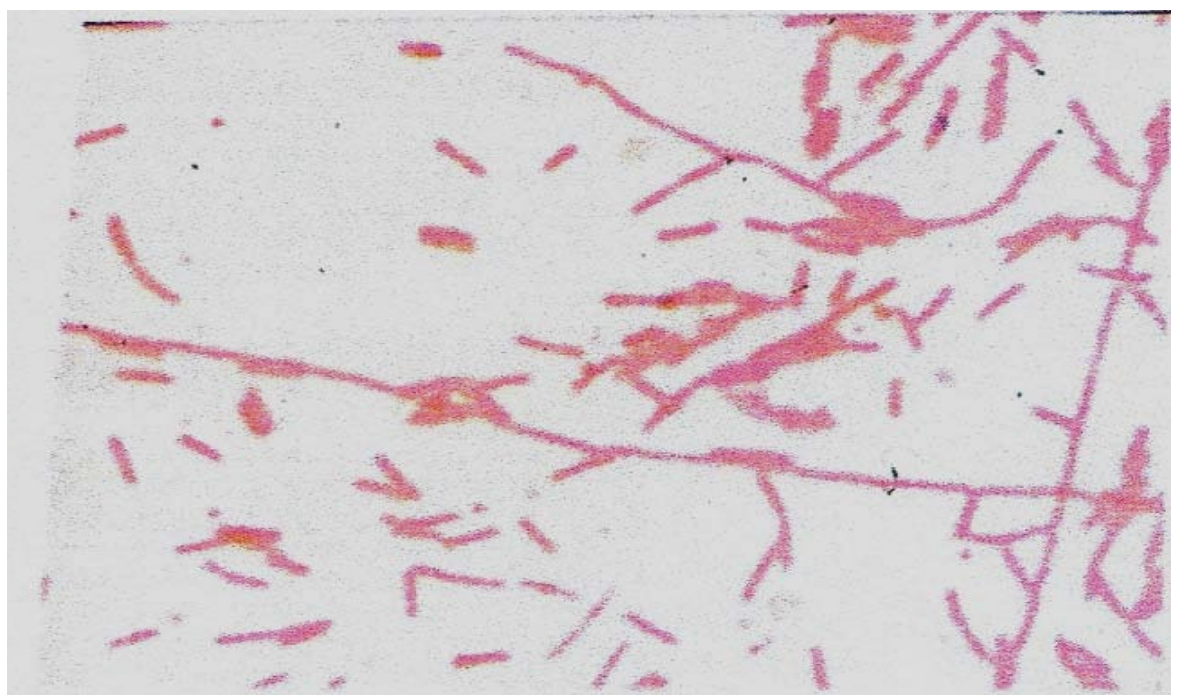

Fig. 7: Legionella pneumophilla cells, courtesy of Jewls, Melnik and Adelbergs

Table 1: Identification of bacteria in the pellicles of the broth culture of

\begin{tabular}{lcc}
\multicolumn{1}{c}{ samples } & $\begin{array}{c}\text { Occurrence in the } \\
\text { turbid portion }\end{array}$ & Percentage \\
\hline Bacteria isolated & 10 & 8.77 \\
Bacillus subtilis & 10 & 8.77 \\
Escherichia coli & 12 & 10.53 \\
Proteus vulgaris & 10 & 8.77 \\
Pseudomonas & 5 & 4.39 \\
Staphylococcus aureus & 1 & 0.88 \\
Streptococcus faecalis &
\end{tabular}

Table 2: Identification of bacteria in the turbid portion of broth cultures of samples

\begin{tabular}{lcc}
\hline \multicolumn{1}{c}{ of samples } & $\begin{array}{c}\text { Occurrence in the } \\
\text { turbid portion }\end{array}$ & $\begin{array}{c}\text { Percentage } \\
\text { Bacteria isolated }\end{array}$ \\
\hline Bacillus subtilis & 20 & 0.88 \\
Escherichia coli & 7 & 17.54 \\
Klebsiella pneumoniae & 27 & 7.89 \\
Legionella & 8 & 23.65 \\
Proteus vulgaris & 9 & 7.02 \\
Pseudomonas & 2 & 7.89 \\
Staphylococcus albus & 11 & 1.75 \\
Staphylococcus aureus & 3 & 7.89 \\
Strptococcus faecalis & 3 & 2.63 \\
Strptococcus sp. & & 2.63 \\
\hline
\end{tabular}

Identification of cells growing in the pellicles were: Escherichia coli with five other bacterial genera as seen in Table 1. Bacterial diagnosed from the turbid portion of broths were listed in Table 2. They include Legionella and Klesbiella pneumoniae. Atotal of eight bacterial genera were diagnosed from the precipitate including 9 species as seen in Table 3. Out of the 114 samples, the number of bacterial isolates and their percentages were listed in Table 4.

Table 4, Legionella cells were identified in $27 \%$ of the 114 samples, (23.65\%) which was alarming. There could have been some Legionella cells in the pellicles and the precipitate of samples that have been missed because
Table 3: Occurrence of bacteria in the precipitate of broth culture

\begin{tabular}{lcc}
\hline Bacteria isolated & $\begin{array}{c}\text { Occurrence in the } \\
\text { turbid portion }\end{array}$ & Percentage \\
\hline Bacillus sterothermophilis & 1 & 0.88 \\
Bacillus subtilis & 2 & 1.75 \\
Escherichia coli & 0 & --- \\
Klubsiella pneumoniae & 0 & --- \\
Legionella & 0 & --- \\
Proteus vulgaris & 0 & --- \\
Pseudo monas & 3 & 2.63 \\
Staphylococcus albus & 1 & 0.88 \\
Staphylococcus aureus & 0 & --- \\
Streptococcus faecalis & 5 & 4.39 \\
Streptococcus sp. & 2 & 1.75 \\
\hline
\end{tabular}

of the heavy bacterial growth. Human waste pollution in Dijla River water ranked high followed by the presence of Legionella (23.65\%). The bacterium Klesbiella pneumoniae that also causes pulmonary infection was isolated from 9 samples (7.89\%) out of the 114 samples. The high number of bacteria present in tap water of Baghdad city revealed that water is not potable.

Effect of storage on Legionella (Shelf life): When Legionella is stored in river water, at room temperature, starting with a count of $10^{8}$ cells $/ \mathrm{mL}$, count remained the same after half an hour but dropped gradually to zero after 4 months (Fig. 8).

To determine the effect of heat on the growth of Legionella cells, an original cell count of $1 \times 10^{8}$ cell $/ \mathrm{mL}$ as determined by dilution to extinction, non-remained viable at $80^{\circ} \mathrm{C}$ after $1 \mathrm{~h}$. The suspension solution was river water (Fig. 9).

To control the existence of Legionella in water supply, heat treatment is more practical, more economical and dependable. For that an original cell count of $1 \times 10^{8}$ cells $/ \mathrm{mL}$ was heated for $1 \mathrm{~h}$ at different temperature 
J. Eng. Applied Sci., 14 (Special Issue 7): 10122-10130, 2019

Table 4: Total bacteria isolated from 114 samples of water coolers in the city of Baghdad

\begin{tabular}{|c|c|c|c|c|c|}
\hline Bacteria & Table 1 & Table 2 & Table 3 & No. of isolates & Percentage \\
\hline Bacillus sterothermophilis & --- & -- & 3 & 3 & 1.63 \\
\hline Bacillus subtilis & 10 & 1 & 4 & 15 & 13.16 \\
\hline Escherichia coli & 10 & 20 & 0 & 30 & 26.32 \\
\hline Klubsiella pneumoniae & --- & 9 & -- & 9 & 7.89 \\
\hline Legionella & --- & 27 & --- & 27 & 23.65 \\
\hline Proteus vulgaris & 12 & 8 & --- & 20 & 17.54 \\
\hline Pseudomonas & 10 & 9 & 3 & 22 & 19.29 \\
\hline Staphylococcus albus & --- & 2 & 1 & 3 & 2.63 \\
\hline Staphylococcus aureus & 5 & 11 & 0 & 16 & 14.04 \\
\hline Streptcoccus faecalis & 1 & 3 & 5 & 9 & 7.89 \\
\hline Streptococcus sp. & -- & 3 & 2 & 5 & 4.38 \\
\hline Total isolates & 48 & 69 & 14 & 131 & \\
\hline
\end{tabular}

1: from the pellicle of nutrient broth; 2: from the turbid portion of the broth; 3 : from the precipitate of the broth

Table 5: Effect of heat on Legionella cells in Dijla water Log no. of Legionella cell in

\begin{tabular}{lll} 
Incubation for $1 \mathrm{~h}\left({ }^{\circ} \mathrm{C}\right)$ & Tap water & River water \\
\hline 40 & 8.0 & 8.0 \\
50 & 6.0 & 7.0 \\
60 & 3.0 & 3.5 \\
70 & 1.0 & 1.5 \\
75 & 0 & 0 \\
80 & 0 & 0 \\
\hline
\end{tabular}

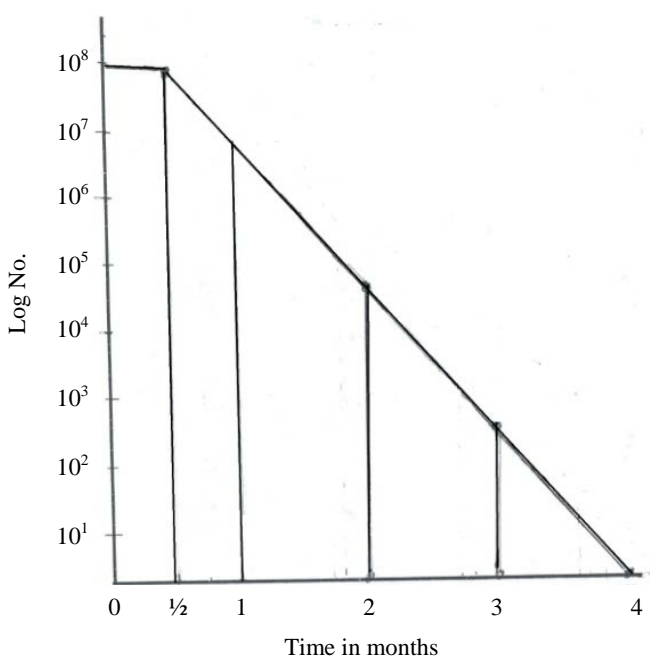

Fig. 8: Survival of Legionella (cells $/ \mathrm{mL}$ ) in Tigris River water stored at room temperature for up to 4 months. Counts were by dilution to extinction

cell count dropped from $\log 8$ to $\log 0 / \mathrm{mL}$ at $75^{\circ} \mathrm{C}$ using Dijla River water and Baghdad tap water, Table 5. Similar results were obtained (Dennis et al., 1984).

At $40^{\circ} \mathrm{C}$ cellular count in tap water and river water was similar (log 8.0) but there was some heat resistance when the cells were heated in Dijla River water. This result could be confirmed by studying the effect of the various element present in water in increasing heat tolerance of cells including Legionella. In the works of kate and Hammed, some Legionella cells resist $70^{\circ} \mathrm{C}$ for $1 \mathrm{~h}$. We did not find living cells growing on blood agar after 4-day incubation at $75^{\circ} \mathrm{C}$ or higher.
Table 6: Susceptibility of Legionella to anti-microbial agents

\begin{tabular}{|c|c|c|}
\hline Amikacin & $30 \mathrm{mg}$ & Sensitive \\
\hline Amoxicillin & $25 \mathrm{mg}$ & Resistant \\
\hline Ampicillin & $10 \mathrm{ug}$ & Resistant \\
\hline Cefixime & 5 ug & Resistant \\
\hline Chloramphenicol & $30 \mathrm{ug}$ & Resistant \\
\hline Doxycycline & 30 ug & Sensitive \\
\hline Erythromycin & $15 \mathrm{mg}$ & Resistant \\
\hline Gentamicin & $10 \mathrm{mg}$ & Resistant \\
\hline Nalidixic acid & $30 \mathrm{ug}$ & Sensitive \\
\hline Nitrofurantoin & $30 \mathrm{ug}$ & Sensitive \\
\hline Penicillin & 10 units & Resistant \\
\hline Rifampicin & $5 \mathrm{mg}$ & Resistant \\
\hline Streptomycin & $10 \mathrm{mg}$ & Resistant \\
\hline
\end{tabular}

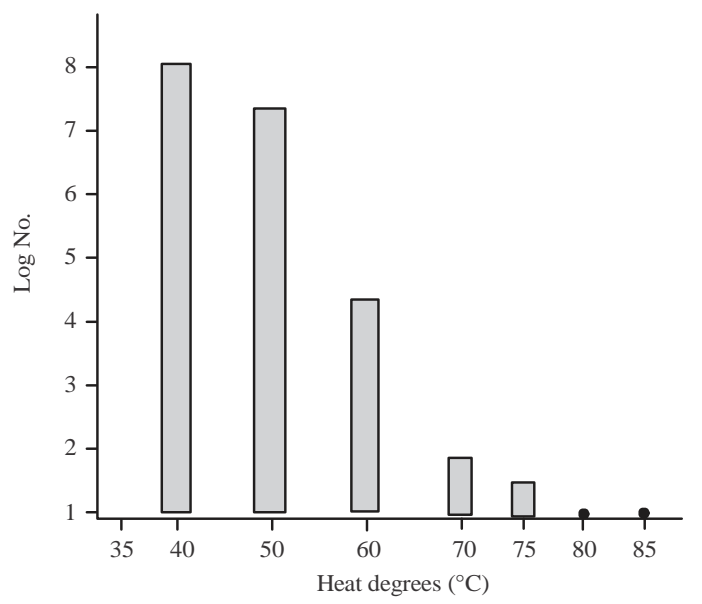

Fig. 9: Effect of heat on viability of isolated Legionella cells in river water

This method would be economical and more reliable than the use of chlorine compounds, ozone, UV light or copper silver ionization. In Iraq, the same tap water is used for air coolers and for drinking. Two bacterial pathogens were found in the tap water of Baghdad city, Legionella and Kleubsiella pneumoniae. It is probable other microbial pathogens could be present. thus increasing the risk of infections. Susceptibility of Legionellato antimicrobial agents showed high resistance Table 6. 
Legionella resists most anti-microbial agents, except Amikacin, Doxycycline, Nalidixic and the Nitro-function. Similar results were reported (Sabria et al., 2006). But there were no results on Nalidixic acid and Nitrofurantoin.

\section{CONCLUSION}

The bacterium Legionella became known to cause pneumonia and febrile illness, since, 1976. It belongs to the family Legionellae, comprising 52 species. The most common species is Legionella pneumophila. The bacterium is aquatic found in rivers, lakes, muds, thriving at warm temperature. This bacterium causes epidemics of respiratory infections known as Legionnaires. Samples were collected from Baghdad city, placed in tubes of nutrient broth having $5 \%$ yeast extract. The diagnostic laboratory was at AL-Nisour University College in Baghdad. The tubes were incubated at $35^{\circ} \mathrm{C}$ for $72 \mathrm{~h}$. Growth appeared as turbidity, some tubes have pellicles, with or without precipitate. Growth from all parts of tubes were sub-cultured on nutrient agar, blood agar EMB and SS agar plates, all plates were incubated at $35^{\circ} \mathrm{C}$ for 1 day but the blood agar plates were placed in a desiccator with humidity and the desiccator was placed in the incubator. Colonies appearing in $24 \mathrm{~h}$ were marked at the back of the blood agar plates, (not being Legionella) and returned to the incubator for a total of $72 \mathrm{~h}$. Colonies appearing on other plates were sub-cultured on the same type of media for purification, gram stain was made from the isolated colonies. Biochemical and physiological reaction were studied. Spore staining was made for the gram positive bacilli and were checked for heat resistant spores by autoclaving and subculturing for diagnosing Bacillus stearotheromophilis. The IMViC tests were done for coliforms. Colonies growing on blood agar plates after $72 \mathrm{~h}$ and longer at $35^{\circ} \mathrm{C}$ incubation under humid environment were described and found to be typical of Legionella, using the physiological and biochemical test (oxide, urease, lecithinaese, coagulase, hipurate, gelatin liquficiation and nitrate reduction that were all found positive. Legionella was isolated from 27 out of 114 samples (23.7\%). The cells were photos. Klesbiella pneumoniae that also causes respiratory tract infections was isolated from 9 out of 114 samples (about 7.9\%). Results were alarming in the water supply of Baghdad city. The heat effect of $80^{\circ} \mathrm{C}$ is not tolerated by Legionella cells, no growth was obtained at $80^{\circ} \mathrm{C}$. Legionella cells remained viable up to 3 months but not after 4 months at room temperature in river water which was the life span of this bacterium. The cells were resistant to most antimicrobial agents, except to Amikacin, Doxycycline, Nalidixic acid and Nitrofurantoin. To avoid legionnaires, we recommend that receiving water for water air coolers is to be heated in a receiving tank and heated to $80^{\circ} \mathrm{C}$ and for $1 \mathrm{~h}$. After cooling water is to be drained or pumped into a tank feeding the water air cooler.

\section{ACKNOWLEDGEMENT}

The researchers are obliged to the excellent efforts of Mr. Mohammed F. Hamza at AL-Bashiq Office solutions in Baghdad, Iraq. For his excellent efforts in the preparation and typing of the manuscript of this study.

\section{REFERENCES}

Al-Sulami, A.A., A.M.R. Al-Taee and A.A. Yehyazarian, 2013. Isolation and identification of Legionella pneumophila from drinking water in Basra governorate, Iraq. East. Mediterr. Health J., 19: 936-941.

Alag, J. and A. Al-Salmi, 2013. Occurrence of Legionella and Hartmennla veriforms in drinking water in Basra Governoret. Ph.D Thesis, Department of Biology, College of Education, University of Basra, Iraq.

Albert-Weissenberger, C., C. Cazalet and C. Buchrieser, 2007. Legionella pneumophila-a human pathogen that co-evolved with fresh water protozoa. Cell. Mol. Life Sci., 64: 432-448.

Anonymous, 2005. Procedure for the recovery of Legionella from environment. US Department of Health and Human Services, Center for Disease Control and Prevention, Atlanta, Georgia.

Atlas, R.M., 1999. Legionella: From environmental habitats to disease pathology, detection control. Environ. Microbiol., 1: 283-293.

Barbaree, J.M., G.W. Gorman, W.T. Martin, B.S. Fields and W.E. Morrill, 1987. Protocol for sampling environmental sites for legionellae. Appl. Environ. Microbiol., 53: 1454-1458.

Bauer, M., L. Mathieu, M. Deloge-Abarkan, T. Remen and P. Tossa et al., 2008. Legionella bacteria in shower aerosols increase the risk of Pontiac fever among older people in retirement homes. J. Epidemiol. Commun. Health, 62: 913-920.

Chamberlain, A.T., J.D. Lenard and R.L. Berkelman, 2017. The 2015 New York city legionnaires disease outbreak: A case study on a history-making outbreak. J. Public Health Manag. Pract., 23: 410-416.

Deadens, B.M.W., 2008. Legionella spp. and Legionnaires disease. J. Inf., 56: 1-12.

Dennis, P.J., D. Green and B.P.C. Jones, 1984. A note on the temperature tolerance of Legionella. J. Appl. Bacteriol., 56: 349-350.

Dennis, P.J., D. Green and B.P.C. Jones, 1984. A note on the temperature tolerance of Legionella. J. Appl. Bacteriol., 56: 349-350.

Ensminger, A.W., 2016. Legionella pneumophila armed to the hilt: Justifying the largest arsenal of effectors in the bacterial world. Curr. Opin. Microbiol., 29: 74-80.

Fisher, 2014. Bacteriological Culture Media. Fisher, Atlanta, Georgia, USA.,. 
Greub, G. and D. Raoult, 2003. Morphology of Legionella pneumophila according to their location within Hartmanella vermiformis. Res. Microbiol., 154: 619-621.

Hensley, J.C., 2009. Cooling towers fundamentals. SPX Cooling Technologies, Inc. Overland Park, Kansas, USA. http://docshare01.docshare. tips/files/681/6811465.pdf

Hsu, S.C., R. Martin and B.B. Wentworth, 1984. Isolation of Legionella species from drinking water. Appl. Environ. Microbiol., 48: 830-832.

Hubber, A. and C.R. Roy, 2010. Modulation of host cell function by Legionella pneumophila type IV effectors. Annu. Rev. Cell Dev. Biol., 26: 261-283.

Hughes, M.S. and T.W. Steele, 1994. Occurrence and distribution of Legionella species in composted plant materials. Appl. Environ. Microbiol., 60: 2003-2005.

Kukla-Lamount, G., 2006. Dorothy Observatory. Columbia University, Palisades, New York, USA.,.

Labora, D.F.C.D., 2018. Difco Manual of Dehydrated Culture Media and Reagents for Microbiological and Clinical Laboratory Procedures. 9th Edn., Franklin Classics Trade Press, USA., ISBN:9780353228429,.

Madigan, M. and J. Martinko, 2005. Brock Biology of Microorganisms. 11th Edn., Prentice Hall, New Jersey, USA.

Mahoney, F.J., C.W. Hoge, T.A. Farley, J.M. Barbaree and R.F. Breiman et al., 1992. Communitywide outbreak of Legionnaires disease associated with a grocery store mist machine. J. Infect. Dis., 165: 736-739.
Nick, J.M. and A. Bennie, 2011. Medical Microbiology. 27th Edn., McGraw Hill, New York, USA.,.

Phin, N., F. Parry-Ford, T. Harrison, H.R. Stagg and N. Zhang et al., 2014. Epidemiology and clinical management of Legionnaires disease. Lancet Infect. Dis., 14: 1011-1021.

Riffard, S., S. Douglass, T. Brooks, S. Springthorpe and L.G. Filion et al., 2001. Occurrence of Legionella in groundwater: An ecological study. Water Sci. Technol., 43: 99-102.

Sabria, M., J. Alvarez, A. Dominguez, A. Pedrol and G. Sauca et al., 2006. A community outbreak of Legionnaires disease: Evidence of a cooling tower as the source. Eur. Soc. Clin. Microbiol. Infect. Dis., 12: 642-647.

Shivaji, T., C.S. Pinto, A. San-Bento, L.A. Oliveira Serra and J. Valente et al., 2014. A large community outbreak of Legionnaires disease in Vila Franca de Xira, Portugal. Eur. Commun. Dis. Bull., 19: 1-4.

Travis, T.C., E.W. Brown, L.F. Peruski, D. Siludjai and P. Jorakate et al., 2012. Survey of Legionella species found in Thai soil. Intl. J. Microbiol., 2012: 1-4.

Velonakis, E.N., I.M. Kiousi, C. Koutis, E. Papadogiannakis and F. Babatsikou et al., 2010. First isolation of Legionella species, including L. pneumophila serogroup 1, in Greek potting soils: Possible importance for public health. Clin. Microbiol. Infect., 16: 763-766. 